\title{
The European wintering population of Steller's Eider Polysticta stelleri reassessed
}

\author{
TOMAS AARVAK, INGAR JOSTEIN ØIEN, YURI V. KRASNOV, \\ MARIA V. GAVRILO and ANATOLY A. SHAVYKIN
}

\section{Summary}

Prolonged declines in the number of Steller's Eider Polysticta stelleri wintering in Europe have raised concerns about the conservation status of the Western Palearctic population. Coordinated helicopter surveys of all known wintering areas in Norway and Russia and ground counts in the Baltic in 2009 found c.27,000 Steller's Eiders, similar to numbers found during the last such survey in the mid-1990s. However, around $85 \%$ of the population now winters in Russia compared to $30-50 \%$ then. The reasons for this rapid shift in distribution are unknown but are likely linked to climate change. The continuing small population size, specialist feeding and restricted distribution of Steller's Eider necessitate continued survey and research to track population changes and provide evidence for conservation management actions to safeguard the species.

\section{Introduction}

The present, but probably highly inaccurate, estimate of the global abundance of Steller's Eider Polysticta stelleri is 110,000-125,000 individuals (BirdLife International 2011), of which 10,00015,000 winter in Europe (Norway, the Baltic, and Kola Peninsula, Russia). This is lower than the estimate of 400,000-500,000 in the 1960s (reviewed in Solovieva et al. 1998), and even less than the estimate of 200,000-220,000 individuals in early 2000 by Žydelis et al. (2006).

The main breeding grounds are along the arctic coasts of Alaska and the Siberian part of the Russian Arctic (from Yamal Peninsula to the Kolyma Delta). A few birds breed in European Russia and there are unconfirmed records of breeding in northern Norway (Petersen et al. 2006).

In the western part of its range, Steller's Eiders winter in the eastern (ice-free) part of the Barents Sea (coastlines of Finnmark, Norway and Murman coast/Kola Peninsula, Russia), White Sea and in the Baltic Sea. Counts in 1994 suggested that $30-50 \%$ of the European population wintered in Russia at that time, but the current status was unknown. The European population was estimated at c.25,000-40,000 individuals in 1994 (Nygård et al. 1995a,b), but significant declines have occurred in all European countries since then. In Norway, the species is almost totally confined to Varangerfjord in Finnmark where numbers declined annually by $8 \%$ in the period $1984-2003$. In Estonia, numbers fell by $9 \%$ during 1992-2004 and in Lithuania by $22 \%$ during 1996-2003 according to Žydelis et al. (2006), who estimated the European wintering population at $10,000-15,000$ individuals, assuming a similar negative trend in Russia as observed in Norway and the Baltic. However, no systematic annual counts were made in Russian areas to confirm that this was the case.

Because of declines in Alaska and Europe, a Steller's Eider recovery plan (U.S. Fish and Wildlife Service 2002) and a similar European Action Plan (Pihl 2001) have been produced for the species.

The reasons for the observed European declines were far from clear and several hypotheses have been put forward to explain the negative trends. A favoured explanation is the winter redistribution of birds from known, well- monitored wintering areas in the west to unmonitored areas in Russia as a result of milder conditions, especially reflected in the annual extent of sea-ice in Russia (Žydelis 
et al. 2006). Steller's Eiders have high annual adult survival rates, and show strong wintering and moult-site fidelity (Flint et al. 2000), so an increase in mortality (due to habitat loss, food availability, excess hunting, fishing activity, contamination or pollution) seemed a more reasonable explanation than a change in site use. Reduction in reproductive success has also been suggested as a contributory factor (Žydelis et al. 2006).

However, the lack of count data relating to wintering Steller's Eiders in European Russia has made it difficult to analyse trends and explain the observed declines, necessitating a new total count of the European wintering population, which we report here.

\section{Methods}

A coordinated aerial count of wintering Steller's Eider was conducted in Norway and Russia in 2009. The Norwegian coast was surveyed over two days, covering the coastline from Berlevåg to Vardø on the northern coast of the Varanger Peninsula, the northern Varangerfjord coast from Varangerbotn to Vardø (30 March) and the southern Varangerfjord coast from Varangerbotn to the Russian border (31 March).

The coasts of the Barent's Sea and White Sea in Russia were surveyed on five different days in the period 24-31 March, covering the Western Kola Bay - Western Murman Coast (27 March), Eastern Kola Bay - Eastern Murman coast (28 March), Eastern Onega Bay - Tersky Coast - Eastern Murman Coast (24 March), Eastern Onega Bay (29 March) and Solovetsky Archipelago - Onega Bay - Dvina Bay (30 March).

The aerial survey in Norway was undertaken with a Bell 206 helicopter following the coastline approximately 300-500 $\mathrm{m}$ offshore. Average helicopter speed and height were $82 \mathrm{~km} / \mathrm{h}$ and $131 \mathrm{~m}$ asl respectively on the stretch from Varangerbotn to Vardø, where the density of birds was high. Speed and height for the surveyed stretch on the east and north sides of the Varanger Peninsula with very few birds averaged $121 \mathrm{~km} / \mathrm{h}$ and $146 \mathrm{~m}$ respectively. One observer sat in front with the pilot doing visual counts and taking notes, and a second observer in the back took photographs of the flocks (Canon $40 \mathrm{OD}$ with Sigma 100-500 mm lens), all in voice contact with each other.

The aerial survey in Russia was undertaken with a Mi-8 helicopter with working speed and height of c. $180 \mathrm{~km} / \mathrm{h}$ and $80 \mathrm{~m}$ asl. respectively. The coastline was followed approximately $300-$ $500 \mathrm{~m}$ offshore, cutting across mouths of small bays and inlets when in ice free areas. In ice-filled waters, survey routes were chosen to follow the ice edge or to cover polynias. Visual counts were performed by a single observer sitting in the front of the helicopter. Recorded data on species composition and numbers were transferred by intercom to an on-board PC operator. The second observer took digital photos of seabird flocks from the open door on the left side of the helicopter (Canon 20D with Canon 70-200 mm lens).

During the survey period in Russia, information on ice conditions was provided on request by the Ice Center, Arctic and Antarctic Research Institute (AARI), Russia, in the form of highresolution MODIS images by e-mail one day before the surveys in order to plan a detailed flight route. Such detailed ice information was not necessary in Norway.

Flight routes and helicopter speed as well as location of all observed birds were plotted by GPS, which was synchronised with time on the cameras.

Sex and age ratios of Steller's Eiders were analysed from photographs. Second calendar yearold males are easily identified based on evident plumage characteristics, while brown, femalelooking individuals were aged on the presence or absence of whitish wing bands (especially in flight) and coloration of the tertials. Most flocks would take off and fly when approached by helicopter and age could readily be determined by the presence or absence of wing bands.

In Norway, not all flocks $(n=21)$ were photographed, so the actual flock size of those not photographed was estimated by the formula $y=1.1331 \mathrm{x}$, calculated by the correlation between the number of birds counted visually and those counted on the accompanying picture. See results for an elaboration of these methodological data. In Russia, no comparison between visual counts and photographs was carried out, so visual count data were used directly in population size estimates. 
The population development of the Norwegian wintering population of Steller's Eider was monitored through annual late winter counts based on ground surveys by car. To evaluate the effectiveness of counts from the shore, a ground-based survey by car was undertaken at the same time as the helicopter survey.

In order to estimate the total population wintering in the Western Palearctic (Russia, Norway and the Baltic), recent literature was searched, the main co-coordinators of national waterfowl and seabird surveys were contacted and they contributed data from their respective countries.

\section{Results}

\section{Total count}

In total, 25,922 Steller's Eiders were counted, 2,697 in Norway and 23,225 in Russia (Table 1). For Norway this represents a decrease of $57.8 \%$ (or $-5.6 \%$ per year) and for Russia an increase of $47.8 \%$ (or $+2.6 \%$ per year), compared to similar aerial counts conducted in 1994 (Nygård et al. 1995b). The Norwegian proportion decreased from $28.9 \%$ to $10.4 \%$ of the total numbers surveyed (Norway + Russia), whereas in Russia, numbers increased from $71.1 \%$ to $89.6 \%$.

\section{Distribution}

In Norway, $76 \%$ of Steller's Eiders were concentrated along the northern coastline of the Varangerfjord. In Russia they were found more or less continuously distributed along the ice-free coast from Ponoy River mouth westwards to Rybachy Peninsula, including Kola Bay (Figure I). Elevated densities were observed east of Svyatoy Nos Cape, where approximately half of the wintering population was concentrated. In Onega Bay, 91 Steller's Eiders were dispersed in polynias in the south-eastern part of the bay, which is the first record of the species there. Of the surveyed sections, the Tersky Coast accounted for $45.8 \%$ of the total (Table 1 ).

\section{Demography}

Based on c.2,00o pictures taken, 3,920 Steller's Eiders in Norway and Russia were sexed and aged. A slightly skewed sex ratio was observed, with $52.0 \%$ males and $48.0 \%$ females. The breeding season in 2008 was poor, with only o.1\% of the aged birds being juveniles (Table 2).

\section{Count methodology}

In Norway the average flock size was 70.7 individuals based on photos $(n=18, \mathrm{SE}=19.0)$ and 62.8 for visual counts $(n=18, \mathrm{SE}=16.1)$ for the same flocks. The correlation between the

Table 1. Number of Steller's Eiders counted along the survey sections in Norway and Russia, March 2009.

\begin{tabular}{lr}
\hline Country & Number \\
\hline Norway & 562 \\
Varanger Peninsula north & 2,061 \\
Varangerfjord north & 74 \\
Varangerfjord south & 3,995 \\
Russia & 456 \\
Western Murman & 6,822 \\
Kola Bay & 11,861 \\
East Murman & 91 \\
Tersky Coast & 0 \\
Onega Bay & 25,922 \\
Dvina Bay & \\
Total & \\
\hline
\end{tabular}




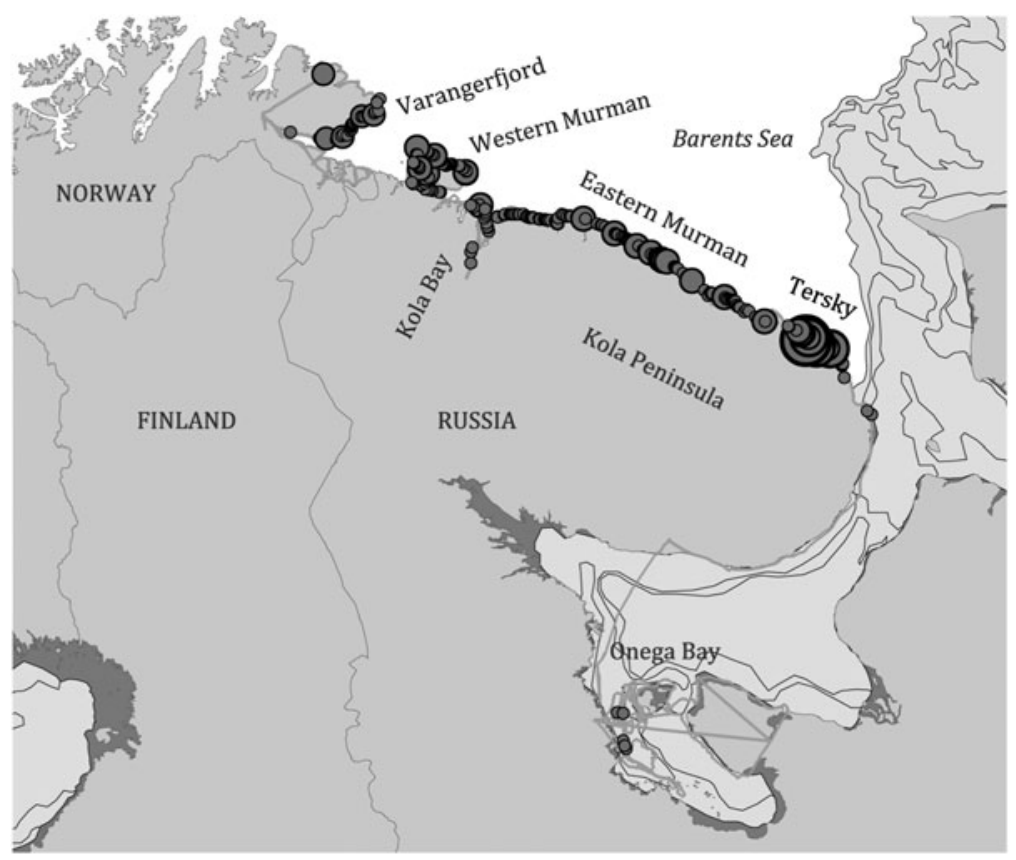

Figure 1. Distribution of Steller's Eiders mapped through aerial surveys in Norway and Russia, March 2009. Red dots scale as 0-100, 101-500, 501-1,000, 1,001-2,000. Yellow lines show survey routes. Light blue colour is drift ice and dark blue is solid ice connected with the mainland on 2 April 2009.

number of birds counted visually and on photos was highly significant $\left(P<0.001, r^{2}=0.9313\right.$, $\mathrm{y}=1.1331 \mathrm{x})$, although the tendency to underestimate flock size increased with increasing flock size $\left(P=0.002, r^{2}=0.4066, \mathrm{y}=0.1834 \mathrm{x}-5.128\right)$ even when the observer was aware of the problem beforehand. The average flock size underestimate for visual counts was 11.1\% (average 7.8 individuals, $n=18, \mathrm{SE}=5.5)$. Correcting for the underestimates, average flock size in Norway was 59.4 individuals $(n=41, \mathrm{SE}=14.7)$. The total underestimate for visual counts from helicopter for Norway was thus $15.5 \%$.

Table 2. Sex and age ratio of Steller's Eiders in Norway and Russia, March 2009.

\begin{tabular}{lrrrrrl}
\hline Survey segment & Males & $\%$ & Females & $\%$ & Imm. & $\%$ \\
\hline Russia & & & & & & \\
Western Murman & 229 & 49.2 & 237 & 50.8 & & 0 \\
Kola Bay & 21 & 52.8 & 19 & 47.2 & & 0 \\
East Murman & 418 & 48.5 & 444 & 51.5 & 4 & 0.5 \\
Tersky Coast & 322 & 55.1 & 262 & 44.9 & & 0 \\
Onega Bay & & & & & & \\
Dvina Bay & & & & & & \\
Norway & 1048 & 53.5 & 912 & 46.5 & 2 & 0.1 \\
Varanger & 408 & 51.8 & 375 & 48.2 & 3 & 0.1 \\
Average $(n=5)$ & 2039 & 52.0 & 1,874 & 47.8 & 6 & 0.2 \\
Total & & & & &
\end{tabular}


Average flock size in Russia was $70.8(n=328, \mathrm{SE}=8.4)$, although with significant variation between the survey sections $(P<0.000, F=15.04, \mathrm{df}=4$; Table 3$)$. The largest observed flock consisted of 2,000 individuals.

To be able to control for methods, a simultaneous land-based survey undertaken by car along the fjord from Varangerbotn to Vardø in the Varangerfjord, Norway, found 1,236 Steller's Eiders. This is $40 \%$ fewer than the 2,061 birds counted during the aerial survey on the similar partial count section.

\section{Western Palearctic population size}

The coastlines of the Baltic countries were not part of the survey in March 2009. However, enquiries to key seabird researchers, experts and contacts in those countries generated good overall count coverage. In Estonia an annual winter survey has been carried out since 1975, giving reasonable coverage in this important country. The total number of Steller's Eider wintering in the Western Palearctic in 2009 was estimated at 27,042, in a year with virtually no young, based on 23,225 in Russia (85.9\%), 2,697 in Norway (10.0\%), 40 in Finland (0.1\%), 20 in Sweden $(<0.1 \%), 1,000$ in Estonia $(3.7 \%)$ (Kuresoo in prep.), 10 in Latvia $(<0.1 \%)$ and 50 in Lithuania $(0.2 \%)$.

\section{Discussion}

This survey confirms no major change in numbers of Steller's Eiders wintering in the Western Palearctic since the mid-1990s, but demonstrates a major redistribution, with $86 \%$ now wintering in Russia compared to 30-50\% in 1994 (Nygård et al. 1995a,b, Žydelis et al. 2006).

Žydelis et al. 2006 considered several likely explanations for the observed declines in Norway and the Baltic and assumed a similar decline in Russia. Shifts in wintering distribution to unknown sites, redistribution in response to climatic factors such as extent of sea ice, changes in bird survey methods and uneven coverage were considered potential explanations. Changes in adult mortality due to habitat loss, illegal hunting, fishing activity/drowning, contamination or pollution were discussed, together with possible changes in reproductive output, although annual data on the proportions of young birds from Finland in spring showed no trend for the years 1975-1995.

Those authors confirmed a significant correlation between the winter NAO index and the change in numbers from one year to the next in Norway that might indicate a shift from Norwegian (and Baltic) wintering areas to Russian wintering areas closer to the breeding grounds (Žydelis et al. 2006). A satellite telemetry study based on 20 birds caught during winter in Norway showed that these did not belong to a discrete breeding population, but spread throughout potential summering areas and tundra breeding habitats from Varangerfjord to the Taimyr Peninsula in the following summer (Petersen et al. 2006). In the subsequent winter, three out of eleven returning birds (27\%)

Table 3. Flock size in Steller's Eiders, March 2009.

\begin{tabular}{lcrr}
\hline Area & Mean & SE & $n$ \\
\hline Norway & & & \\
Varanger & 59.4 & 14.7 & 41 \\
Russia & & & 163 \\
Eastern Murman & 41.9 & 3.6 & 13 \\
Kola Bay & 35.1 & 8.6 & 5 \\
Onega bay & 18.2 & 10.7 & 60 \\
Tersky coast & 197.7 & 39.9 & 87 \\
Western Murman & 45.9 & 7.1 & 328 \\
Russia total & 70.8 & 8.4 & \\
\hline
\end{tabular}


did not return to Varangerfjord, but wintered along the Kola Peninsula coast. The satellite tracking was also unable to demonstrate clear relationships between breeding, wintering and moult aggregations, which confirmed the findings of Dau et al. (2000) who found signs of subpopulation structuring amongst Steller's Eiders using moulting areas in the Pacific population.

Ringing recovery data from Russia showed a significant increase in migration distance from the period 1961-1970 (mean 2,517 km) to 1971-1980 (3,078 km) and 1991-2000 (3,336 km) (Dobrynina and Kharitonov 2006), which fits with the observed increase in Norway and Baltic from the 1980s and up to the mid-199os. Unfortunately no data were available for the last 10-year period when the population has undergone a reduction in numbers along the Baltic/Norwegian coasts.

In light of the changes in distribution and numbers we have no good explanation for the observed patterns. Changes in the extent of ice-coverage in the Barents Sea are likely to influence the distribution patterns. Since the maximum in 1979, there was an overall decrease in ice until the early 1990s when the extent increased with a new maximum in 1998-1999. Since then the ice coverage has steadily decreased (data from Ice-service, the Norwegian Meteorological Institute). Annual winter count data (data provided by A. Kuresoo) from 1975 to 2007 in Estonia was not significantly correlated with total amount of sea ice (monthly average in December-February) in the Barents Sea $\left(P=0.53, r^{2}=-0.113, n=33\right)$, as was neither the case with winter count data from Norway (Nygård et al. 1995a,b, Žydelis et al. 2006, Norwegian national winter monitoring programme) $\left(P=0.89, r^{2}=-0.030, n=25\right)$. However, the counts carried out in Norway have partly been undertaken by unskilled observers and in some years did not cover the whole survey section, thus creating noise around the validity of the time-series data. Another source of variation is detection probability. As demonstrated in the present study, a substantial number of birds present were not observed during the ground survey, and how this varies between years and meteorological conditions is unknown and should be studied further.

The survey results confirm the need for improved coordinated monitoring of the winter distribution and abundance of Steller's Eiders in the Western Palearctic. Ideally, an annual survey along the lines presented here should be undertaken, together with an annual assessment of the sex and age ratio to contribute to modelling the population dynamics. This is even more important in light of the ongoing large-scale changes in habitat and climatic conditions (both in terrestrial and marine ecosystems) due to climate warming (Møller et al. 2010). Modelling studies on Spectacled Eider Somateria spectabilis and Steller's Eider suggest that a warming of $4-6^{\circ} \mathrm{C}$ by AD 2040 would likely expand the potential nesting habitat of both species (Fox 2010); however, due to the complex effects of climate warming on the food supply and predators, it is at present impossible to predict if such changes will be beneficial or not, even more reason to monitor distribution, abundance and demographics of this iconic northern species.

\section{Acknowledgements}

Our gratitude goes to Morten Ekker at the Norwegian Directorate for Nature Management (DN) for invaluable help during the survey. Nick Hughes at the Ice-service, the Norwegian Meteorological Institute, kindly provided ice data from the Barents and White Seas within the survey period and additional long-trend data (1979-2008) of ice distribution in the Barents Sea. Vladimir Bessonov from the Ice Center, Arctic and Antarctic Research Institute (AARI), Russia, kindly provided ice data based on high-resolution MODIS images to plan the aerial survey in Russia. We thank SPARC+ aviation enterprise and the Mi-8 helicopter pilots for good service and cooperation during survey flights in Russia and similarly to Arctic Helicopter Service AS in Norway. Mindaugas Dagys in Lithuania, Andres Kuresoo in Estonia, Antra Stīpniece in Latvia, Petteri Tolvanen and Martti Hario in Finland and Leif Nilsson in Sweden kindly provided winter population estimates and advice about Steller's Eiders in their respective countries. The survey was financed by the Norwegian Ministry of the Environment (MD) and DN through the bilateral Environmental Cooperation Agreement between Norway and Russia. We are grateful to Prof. Anthony D. Fox and an anonymous referee for valuable contributions to the final manuscript. 


\section{References}

BirdLife International (2011) Species factsheet: Polysticta stelleri. Downloaded from http://www.birdlife.org on 12/01/2011.

Dau, C. P., Flint, P. L. and Petersen, M. R. (2000) Distribution of recoveries of Steller's Eiders banded on the lower Alaska Peninsula, Alaska. J. Field Ornithol. 71: 541-548.

Dobrynina, I. N. and Kharitonov, S. P. (2006) The Russian waterbird migration atlas: temporal variation in migration routes. Pp. $582-$ 589 in G. C. Boere, C. A. Galbraith and D. A. Stroud, eds. Waterbirds around the world. Edinburgh, UK: The Stationery Office.

Flint, P. L., Petersen, M. R., Dau, C. P., Hines, J. E. and Nichols, J. D. (2000) Annual survival and site fidelity of Steller's Eiders molting along the Alaska Peninsula. J. Wildl. Manage. 64: 261-268.

Fox, G. W. (2010) Bird migration and global change. Washington: Island Press.

Kuresoo, A. (In prep.) Action plan of Steller's Eiders in Estonia 2012-2016.

Møller, A. P., Fiedler, W. \& Berthold, P. (2010) Effects of climate change on birds. New York: Oxford University Press.

Nygård, T., Frantzen, B., and Svazas, S. (1995a) Steller's Eiders Polysticta stelleri wintering in Europe: number, distribution and origin. Wildfowl 46: 140-155.

Nygård, T., Jordhøy, P., Kondakov, A. and Krasnov, Yu. (1995b) A survey of water- fowl and seal on the coast of the southern Barents Sea in March 1994. NINA Oppdragsmelding 361: 1-24 (in Norwegian with English summary).

Petersen, M. R., Bustnes, J. O. and Systad, G. H. (2006) Breeding and moulting locations and migration patterns of the Atlantic population of Steller's Eiders Polysticta stelleri as determined from satellite telemetry. J. Avian Biol. 37: 58-68.

Pihl, S. (2001) European species action plan for Steller's Eiders (Polysticta stelleri). Pp. $1-26$ in N. Schäffer and U. Gallo-Orsi, eds. European Union action plans for eight priority bird species. Luxembourg: Office for Official Publications of the European Community.

Solovieva, D. V., Pihl, S., Fox, A. D. and Bustnes, J.-O. (1998) Polysticta stelleri Steller's Eiders. BWP Update 2: 145-158.

U.S. Fish and Wildlife Service (2002) Steller's Eiders recovery plan. Fairbanks, Alaska: U.S. Fish and Wildlife Service.

Žydelis, R., Lorentsen, S-H., Fox, A. D., Kureso, A., Krasnov, Y., Goryaev, Y., Bustnes, J. O., Hario, M., Nilsson, L. and Stipniece, A. (2006) Recent changes in the status of Steller's Eiders Polysticta stelleri wintering in Europe: a decline or redistribution? Bird Conserv. Internatn. 16: 217236.

\section{TOMAS AARVAK*, INGAR JOSTEIN ØIEN}

Norwegian Ornithological Society/BirdLife Norway, Sandgt.3ob, N-7012 Trondheim, Norway.

\section{YURI V. KRASNOV}

Murmansk Marine Biological Institute, Vladimirskaya 17, Murmansk 183010, Russian Federation.

\section{MARIA V. GAVRILO}

Arctic and Antarctic Research Institute, 38 Bering str., St.Petersburg, Russian Federation, present address National Park Russian Arctic, 57 Sovetskikh Kosmonavtove ave., Archangelsk, Russia.

\section{ANATOLY A. SHAVYKIN}

Murmansk Marine Biological Institute, Vladimirskaya 17, Murmansk 183010, Russian Federation.

*Author for correspondence; e-mail: tomas@birdlife.no

Received 6 January 2012; revision accepted 6 May 2012; Published online 4 July 2012 